\title{
MORPHOLOGICAL AND MOLECULAR CHARACTERIZATION OF ITALIAN, IRANIAN AND SPANISH SAFFRON (CROCUS SATIVUS L.) ACCESSIONS
}

\author{
TORRICELLI, R. ${ }^{1}$ - YOUSEFI JAVAN, I. ${ }^{2 *}$ - ALBERTINI, E. ${ }^{3}-$ VENANZONI, R. ${ }^{3}-$ HOSSEINZADEH, Y. G. ${ }^{3}$ \\ ${ }^{1}$ Dipartimento di Scienze Agrarie Alimentari e Ambientali, University of Perugia \\ Borgo XX, Giugno 74, 06121 Perugia, Italy \\ ${ }^{2}$ Department of Plant Production, Faculty of Agriculture, University of Torbat Heydarieh, \\ Torbat Heydarieh, Iran \\ (ORCID ID: 0000-0001-6906-8626; phone: +98-51-51240177) \\ ${ }^{3}$ Dipartimento di Chimica, Biologia e Biotecnologie, University of Perugia \\ Borgo XX Giugno, 74, 06121 Perugia, Italy \\ *Corresponding author \\ e-mail:I.Javan@torbath.ac.ir \\ (Received $27^{\text {th }}$ Oct 2018; accepted $11^{\text {th }}$ Jan 2019)
}

\begin{abstract}
The use of saffron dates back to ancient times. It is commonly used in medicine, as well as the function of dye and spice in the food industry. The oldest documents about the edible use of saffron are recorded by Polyen (in the 2nd century BC), a Greek military writer who, in his graduation thesis entitled "Stratagemes" reports a list of foods consumed by the court of the Persian Achemenide dynasty (550-330 BC), which had been carved on a bronze column in front of the kitchen (Abrishami, 2004). Its cost is variable according to the production vintage and drying methodologies, it can reach up to 20,000 euros per kilo. The reason for the very limited genetic diversity in cultivated saffron is explained by its asexual mode of reproduction. The AFLP technique could be a good choice to investigate the genetic diversity because of its high-multiplex-ratio which allows detecting differences even between samples sharing most of the genetic material, and it is still one of the most used tools for the molecular characterization of genetic variability in cultivated plants. The aim of this study was to assess the variability of morpho-physiological traits and to evaluate the genetic differences among different proveniences of $C$. sativus with AFLP. The results of this paper in part confirm those obtained by previous studies. Despite morphological differences found between the accessions, molecular markers have revealed limited genetic differences for samples with different origin.
\end{abstract}

Keywords: AFLP, Crocus sativus L., morphology characterization, genetic diversity, molecular markers, genetic pool

\section{Introduction}

Saffron (Crocus sativus L.), with a basic chromosome number of $\mathrm{x}=8$, is a triploid and sterile plant, is propagated exclusively by vegetative means (Petersen et al., 2008; Agayev et al., 2009) via its corms which undergo a period of dormancy (Fernandez, 2004).

Saffron is one of the most expensive spices in the world because of the high demand and the different uses, but also for the high costs of cultivation and production. Saffron consists of the dried dark red "stigmas" of the Crocus sativus, flower (Chryssanthi et al., 2007), which on average weighs about $6 \mathrm{mg}$. Therefore, approximately 150,000 to 200,000 flowers are required to yield $1 \mathrm{~kg}$ of saffron spice. It is worth nothing that its high price reflects the time required for its cultivation, harvesting and handling (separation of stigma from other parts of the flower parts). In order to gather the saffron, the stigmas of 
the saffron flower must be handpicked. This becomes very time consuming, considering that in order to produce just $1 \mathrm{~g}$ of saffron, need to collect an average of 150 flowers (Hosseinzadeh Gonabad, 2013).

In addition to its culinary uses, saffron has a long history as a potent component of traditional medical systems (Gutheil et al., 2012; Premkumar et al., 2006; Abdullaev, 2002; Kim et al., 2014).

Like most plant derivatives, saffron contains a multitude of bioactive molecules. Chief among these molecules are crocin, crocetin, and safranal, members of the carotenoid family of molecules that also includes forms of vitamin A (Aung et al., 2007).

Commercial saffron (dried stigmata of Crocus sativus L.) contains: crocin and crocetin (colors) Crocin is the principle coloring pigment, at nearly 10\% (Pfander and Wittwer, 1975; Tsimidou and Tsatsaroni, 1993), picrocrocin (bitter principle), the glycoside picrocrocin which is a precursor of safranal and responsible for its distinctly bitter flavour safranal (flavor), safranal, is the deglycosylated form of picrocrocin and the major organoleptic principle of the stigmas.

Its cultivation has long been concentrated on a broad belt of Eurasia, bounded by the Mediterranean Sea in the Southwest, to Kashmir and China in the northeast. Iran is the main producer of saffron, accounting for more than $90 \%$ of world production (about 300 tonnes in the year 2017), followed by India (5\%) and countries of the Mediterranean basin (Greece, Morocco, Spain, Italy and Turkey) (Gresta et al., 2008a). However, the Mediterranean region is recognized worldwide as producing the best quality of saffron, which is attributed to many factors (Gresta et al., 2008b; Lage and Cantrell, 2009).

About crocus cultivation in Europe one theory states that Moors reintroduced saffron corms to the region around Poitiers in AD 732 (Pearce, 2005). Two centuries after their conquest of Spain, Moors planted saffron throughout the southern provinces of Andalucía, Castile, La Mancha, and Valencia. Later the proliferation of saffron began to spread throughout Europe (Abrishami, 1987, 2004). Today Spain is the biggest exporter of saffron in the world. Every year, a saffron festival (Fiesta de la Rosa del Azafran) takes place in Spain, consisting of competition for the best saffron dish and saffron picking contest. In Spain there are many dishes which need saffron; the most important one is Paella (Abrishami, 1987; Winterhalter and Straubinger, 2000; Dadkhah et al., 2003).

Archaeological records indicate that saffron was cultivated and used as a spice or medicinal plant in the Mediterranean basin as early as the late Bronze Age. However, there is no consensus on where the first saffron plants were domesticated and grown (Grilli Caiola and Canini, 2010; Molina et al., 2015).

Saffron is one of the oldest crops, which, despite its long history of cultivation compared to conventional crops, is still mainly grown in marginal lands and in low-input farming systems. Therefore, it can be considered an alternative crop in sustainable agricultural systems and marginal land with low efficiency. Several years of studies have demonstrated that differences in saffron quality can be due to environmental effects, postharvest processing the stigmas, and any genetic variation (Agayev et al., 2006; Nehvi et al., 2007; Ghaffari and Bagheri, 2009; Fluch et al., 2010; Siracusa et al., 2013; Babaei et al., 2014).

Recent studies carried out with molecular techniques have demonstrated that genotype could also play a very important role. The high price of saffron makes it frequent subject of adulteration of various types, i.e. including the mixing authentic Saffron stigmas with other plants flowers colored with natural or artificial dyers. Therefore, the development of 
molecular tools could be fundamental not only to control the purity of saffron products, avoiding adulteration but also for tracing the origin of pure saffron products.

DNA markers have been used in Crocus spp. to characterize germplasm collections, inform breeding programs, and facilitate genetic diversity studies and taxonomic analysis. Over the last decade some technological advances in DNA marker techniques were made. The methods include: random amplified polymorphic DNA (RAPD) (Grilli Caiola et al., 2004; Beiki et al., 2010; Rubio Moraga et al., 2010); ii) inter-retrotransposon amplified polymorphism (IRAP) (Alavi Kia et al., 2008); iii) amplified fragment length polymorphism (AFLP) (Zubor et al., 2004; Erol et al., 2011; Nazzal et al., 2011; Siracusa et al., 2013); iv) intersimple sequence repeat (ISSR) (Rubio Moraga et al., 2010); v) simple sequence repeat (SSR) (Rubio Moraga et al., 2010; Nemati et al., 2012); and vi) single-nucleotide polymorphism (SNP) (Syvanen, 2001; Singh et al., 2010).

Among these molecular markers, AFLPs, based on the selective PCR amplification of restricted total DNA fragments (Vos et al., 1995; Powell et al., 1996) were found to show high levels of polymorphisms per primer combination and yielded high resolution and reproducibility (Meudt and Clarke, 2007; Erol et al., 2014). AFLPs could then be a good choice for investigating genetic variability among saffron accessions because of its highmultiplex-ratio which allows detecting differences even between samples sharing most of the genetic material (Vos et al., 1995). In recent years we successfully have applied AFLP for dissecting genetic variability in faba bean (Gresta et al., 2010), in lentil, (Torricelli et al., 2012), celery (Torricelli et al., 2013), olive (Albertini et al., 2011) and saffron (Siracusa et al., 2013).

The aim of this study was to assess the variability of morpho-physiological traits in $C$. sativus populations coming from Iran and Italy and to evaluate the genetic differences among different origins (Iran, Italy and Spain) with AFLP markers. here are many advantages to AFLP when compared to other marker technologies including RAPD, RFLP, SSRs and SNPs. AFLP not only has higher reproducibility, resolution, and sensitivity at the whole genome level compared to other techniques, but it also has the capability to amplify between 50 and 100 fragments at one time. In addition, no prior sequence information is needed for amplification (Meudt and Clarke, 2007).

\section{Materials and methods}

\section{Morphological analysis}

Corms coming from Iran (6 accessions) and from Italy (2 accessions) (Table 1) were planted in September 2012 on a sandy-clay soil in Umbria, Central Italy (220 m a.s.1.). Sowing was executed in raised beds at $20 \mathrm{~cm}$ depth $50 \mathrm{~cm}$ between rows and $20 \mathrm{~cm}$ between corms in rows. A complete randomized block design with two replications was adopted. Fifteen corms per accession per replication were used; no fertilizer and no irrigation were applied. Weeds were managed by hand. Seventeen morpho-physiological traits were recorded per single plant; detailed information about the recorded traits is reported in Table 2.

\section{DNA extraction and AFLP analysis}

About eighty days after transplant, leaf tissues were collected for DNA extraction, which was carried out on a single plant basis using the DNeasy 96 Plant Kit and an MM300 Mixer Mill (Qiagen GmbH, Hilden, Germany). In addition to the saffron 
accessions used for the morphological characterization, two Italian populations (Cascia PG and S. Anatolia di Narco - PG) and one population coming from Spain (Mancha) for molecular analysis were used (Table 1). For each population 3 plants were used as biological replicas. DNA was concentrated and quality was assessed using a Thermo Scientific NanoDrop 1000 ultraviolet spectrophotometer and confirmed by agarose gel electrophoresis.

Table 1. List of saffron accessions used in morpho-physiological and genetic analysis altitude, rainfall and geographical coordinates

\begin{tabular}{c|c|c|c|c}
\hline \multicolumn{2}{c|}{ Accessions } & m a.s.l. & $\begin{array}{c}\text { Average annual rainfall } \\
(\mathbf{m m})\end{array}$ & $\begin{array}{c}\text { Geographic } \\
\text { coordinates }\end{array}$ \\
\hline 1 & Citta della Pieve - Italy & 509 & 805 & $42^{\circ} 57^{\prime} \mathrm{N} 12^{\circ} \mathrm{E}$ \\
2 & Rahn - Iran & 1100 & 140 & $43^{\circ} 21^{\prime} \mathrm{N} 58^{\circ} 41^{\prime} \mathrm{E}$ \\
3 & Tapeh Righ - Iran & 1100 & 140 & $43^{\circ} 21^{\prime} \mathrm{N} 58^{\circ} 41^{\prime} \mathrm{E}$ \\
4 & Ghassabbeh - Iran & 1100 & 152 & $43^{\circ} 21^{\prime} \mathrm{N} 58^{\circ} 41^{\prime} \mathrm{E}$ \\
5 & Torbat Heidarieh - Iran & 1340 & 180 & $35^{\circ} 17^{\prime} \mathrm{N} 59^{\circ} 12^{\prime} \mathrm{E}$ \\
6 & Ghaien - Iran & 1340 & 152 & $33^{\circ} 43^{\prime} \mathrm{N} 59^{\circ} 11^{\prime} \mathrm{E}$ \\
7 & Torbat - Market - Iran & 631 & $35^{\circ} 17^{\prime} \mathrm{N} 59^{\circ} 12^{\prime} \mathrm{E}$ \\
8 & Barisciano - Italy & 1050 & $42^{\circ} 19^{\prime} \mathrm{N} 13^{\circ} 35^{\prime} \mathrm{E}$ \\
$* 9$ & Cascia - Italy & 653 & 1080 & $42^{\circ} 43^{\prime} \mathrm{N} 13^{\circ} 1^{\prime} \mathrm{E}$ \\
$* 10$ & S. Anatolia di Narco - Italy & 328 & 370 & $42^{\circ} 44^{\prime} \mathrm{N} 12^{\circ} 50^{\prime} \mathrm{E}$ \\
$* 11$ & Mancha - Spain & 700 & $39^{\circ} 51^{\prime} \mathrm{N} 4^{\circ} 1^{\prime} \mathrm{O}$ \\
\hline
\end{tabular}

*Supplementary accessions used in genetic analysis

Table 2. Morpho-physiological traits recorded and their codes

\begin{tabular}{l|c}
\hline \multicolumn{1}{c|}{ Traits } & Code \\
\hline 1. Days to emergence (days from October 15) & DEME \\
2. Buds number in vegetation & BUNU \\
3. Leaves number per bud & LENU \\
4. Sheath height (mm) & SHE \\
5. Main leaf length (cm) & MLL \\
6. Main leaf width (cm) & MLW \\
7. Leaf area (cm2) & LEA \\
8. Dry flower weight (mg) & DFW \\
9. Dry weight of stigmas (mg) & DWS \\
10. Tepals length (mm) & TEL \\
11. Tepals width (mm) & TEW \\
12. Anther length (mm) & ANTL \\
13. Stigma length (mm) & STIL \\
14. Corms number per plant & CORN \\
15. Corms diameter (mm) & CORD \\
16. Flowers number per plot & FNPLO \\
17. Flowers number per plant & FNPLA \\
\hline
\end{tabular}


All amplifications were performed on Gene Amp PCR System 9600 (Perkin Elmer, USA). One microliter of each sample was combined with $10 \mu \mathrm{l}$ of Hi-Di formamide, $0.25 \mu 1$ size standard Liz 500 (Applied Biosystems), denaturated and fractionated on an ABI 3130xl capillary sequencer (Applied Biosystems).

AFLP analysis was carried out according to (Vos et al., 1995) with minor modification as reported by (Albertini et al., 2011). Genomic DNA (300 ng) was restricted with EcoRI /MseI enzyme combination and double-strand adaptors were ligated to fragment ends. Pre-amplification of the diluted (10-fold) ligated DNA was performed using primers carrying one selective nucleotide (EcoRI $+\mathrm{C}, \mathrm{MseI}+\mathrm{A})$. The pre-amplification products were diluted 10-fold and used as a template for the selective amplification. Selective amplifications were performed by using fluorescent-labeled EcoRI+3 primer and unlabeled MseI+3 primer (Table 6).

\section{Statistical data analysis (morpho-physiological data)}

For the morpho-physiological data, ANOVA (Analysis of variance) was carried out using PROC GLM of SAS (SAS, 2008). Means were compared using Duncan's multiple range test. Finally, Pearson's correlation between each couple of morphophysiological was also calculated. In order to summarize all the information from the collected data, a Principal Component Analysis (PCA) was performed.

\section{Molecular data}

5 AFLP fragments were scored dominantly and recorded in a 0/1-matrix for the peak absence/presence along with their sizes using the Genemapper 4.0 software (Applied Biosystems). Molecular data were arranged in a data matrix. The number and percentage of polymorphic loci were calculated for each marker and in total on the entire data set. Number of private bands within an accession (i.e. bands belonging only to a certain farmer population or variety) were also counted. AFLP fragments were scored as 1 or 0 for presence or absence of the band, respectively, using the Genescan software (Applied biosystem). Genetic similarity (GS) was estimated using the similarity coefficient of Jaccard (1908): SGij = a / $(a+b+c)$, where GSij is the genetic similarity between individual $\mathrm{i}$ and $\mathrm{j}$; $\mathrm{a}$ is the number of polymorphic bands that are shared by $i$ and $j, b$ is the number of bands present in $i$ and absent in $j$, and $c$ is the number of bands present in $\mathrm{j}$ and absent in $\mathrm{i}$. Genetic similarities among samples were clustered by the unweighted pair-group method of arithmetic average (UPGMA; Sneath and Sokal, 1973). The statistical analyses were worked out using the SAS Institute Inc. (SAS, 2008) and NTSYS-PC Version Q 2.11 (Rohlf, 1993) software.

\section{Results}

\section{Morpho-physiological analysis}

Based on results of ANOVA the accessions of $C$. sativus differed in most characteristics. The average values of the evaluated traits, compared by using the Duncan's multiple range test, are shown in Table 3. There were no significant differences for following traits: sheath height (SHE), main leaf length (MLW), tepals length (TEL), tepals width (TEW) and corms number produced per plant (CORN). Significant difference was detected among accessions for all other traits (value $\mathrm{P}<0.05$ ). In particular regarding days to emergence (DEME), Barisciano and Torbat 
Market were the earliest populations, while Ghaien and Rahn were the latest. Città della Pieve accession shows the highest buds number in vegetation (BUNU) per plant (5.27) while Rahn has the lowest buds number (2.36). Barisciano and Città della Pieve have the highest number leaves per bud (LENU), 10.00 and 9.54 respectively. Barisciano and Città della Pieve populations highlighted the highest corms diameter (CORD), 31.35 and 23.34. Regards the flowers production (per plot and per plant), the Italian saffron populations were the most yielded. The correlation matrix between morphological traits was summarized in Table 4. Pearson's coefficients were calculated, significant differences were found and will be taken into account only those traits related to the spice and corms production. Days to emergence (DEME) is negatively correlated with flower number per plot (FNPLO) $(\mathrm{r}=-0.54)$ and flower number per plant (FNPLA) $(\mathrm{r}=-0.59)$. Buds number in vegetation (BUNU) is positively correlated with corms number per plant (CORN) and flower number per plot (FNPLO) $(\mathrm{r}=0.70)$. Leaves number per bud (LENU) is positively correlated with dry weight of stigmas (DWS), corms diameter (CORD) and flower number per plant (FNPLA) $(r=0.65,0.75$ and 0.94, respectively). Stigma length (STIL) is positively correlated with dry flower weight (DFW), dry weight of stigmas (DWS), corms diameter (CORD) and flower number per plant (FNPLA) $(r=0.80,0.88,0.65$ and 0.78 respectively). Anther length (ANTL) is positively correlated with flower number per plant (FNPLA) $(r=0.83)$. Corms diameter (CORD) is highly correlated with flower number per plot (FNPLO) $(r=0.72)$ and flower number per plant (FNPLA) $(r=0.80)$. Finally, dry weight of stigmas (DWS) is positively correlated with anther length (ANTL), corms diameter (CORD) and flower number per plant (FNPLA) ( $\mathrm{r}=0.76,0.66$ and 0.74 respectively). To summarize all the variability among the saffron accessions a principal component analysis (PCA) was worked out by using averages of data recorded per accession. The first three components (PC1, PC2 and PC3) of the PCA accounted for 46.15\%, 26.82\% and $12.03 \%$ of the total variation, respectively (85.00\% of total variation) (Table 5). Eigenvectors (Table 5) showed that: i) PC1 was highly correlated with flowers number produced per plot (FNPLO) (0.35), flowers number produced per plant (FNPLA) (0.34), leaves number per bud (LENU) (0.34), anther length (ANTL) (0.33) and stigma length (STIL) (0.32); ii) PC2 was highly correlated with main leaf length (MLL) (0.45), leaf area (LEA) 0.44), main leaf width MLW (0.35) and tepals length (TEL) (0.34); iii) PC3 was highly correlated with tepals width (TEW) (0.53) and Dry flower weight DFW (0.47). The plot of PC 1 and PC2 is shown in Figure 1. From the scatter plot it is clear that the Italian saffron populations are separated clearly from the Iranian accessions. This separation is mainly due to PC1. The saffron accession which comes from the market (Torbat Market) is separated from all other Iranian accessions especially thanks to the second main component (PC2). The cultivated saffron populations coming from Iran are subdivided into two main groups, the first group comprises Rhan and Ghaien; the second group includes Ghassabeh, Tapehrigh and Torbat. With regard to the morpho-physiological traits the Iranian accessions highlight among them some phenotypic diversity.

\section{Molecular analysis}

A total of 22 samples ( 2 samples per accession) were genotyped using 8 AFLP primer combinations and a total of 318 amplification products were scored (Table 6). Detected polymorphisms range from 0\% (Eco-CCA/Mse-ATC and Eco-CCA/MseAGC) to $8.51 \%$ (Eco-CCA/Mse-AGC) depending on the primer combination, with an 
average of $4.13 \%$. The molecular weight of the amplification products ranged from 51 to $389 \mathrm{bp}$. and the average number of bands scored per reaction was 39.75 with a variation from 24 (Eco-CAA/Mse-ACA) to 61 (Eco-CCA/Mse-AGC).

Table 3. Saffron accessions, average values of the evaluated traits and the Duncan's multiple range test

\begin{tabular}{c|c|c|c|c|c|c|c|c}
\hline \multirow{2}{*}{ Traits } & \multicolumn{7}{|c}{ Accessions } \\
\cline { 2 - 8 } & $\begin{array}{c}\text { Città della } \\
\text { Pieve }\end{array}$ & Rahn & Tapeh Righ & Ghassabbeh & $\begin{array}{c}\text { Torbat } \\
\text { Heidarieh }\end{array}$ & Ghaien & $\begin{array}{c}\text { Torbat } \\
\text { Market }\end{array}$ & Barisciano \\
\hline DEME & $11.20 \mathrm{AB}$ & $14.30 \mathrm{AB}$ & $11.25 \mathrm{AB}$ & $9.77 \mathrm{~B}$ & $13.24 \mathrm{AB}$ & $15.60 \mathrm{~A}$ & $4.10 \mathrm{C}$ & $3.45 \mathrm{C}$ \\
BUNU & $5.27 \mathrm{~A}$ & $2.36 \mathrm{D}$ & $3.14 \mathrm{CD}$ & $2.60 \mathrm{CD}$ & $2.68 \mathrm{CD}$ & $2.43 \mathrm{D}$ & $4.30 \mathrm{~B}$ & $3.45 \mathrm{C}$ \\
LENU & $9.54 \mathrm{~A}$ & $4.72 \mathrm{C}$ & $5.03 \mathrm{C}$ & $4.34 \mathrm{C}$ & $4.55 \mathrm{C}$ & $4.79 \mathrm{C}$ & $6.44 \mathrm{~B}$ & $10.00 \mathrm{~A}$ \\
SHE & 17.90 & 14.00 & 14.56 & 16.60 & 18.09 & 16.17 & 18.20 & 15.30 \\
MLL & $21.84 \mathrm{BC}$ & $21.23 \mathrm{C}$ & $23.45 \mathrm{ABC}$ & $25.23 \mathrm{AB}$ & $22.82 \mathrm{ABC}$ & $20.87 \mathrm{C}$ & $25.70 \mathrm{~A}$ & $23.10 \mathrm{ABC}$ \\
MLW & 0.26 & 0.26 & 0.28 & 0.27 & 0.25 & 0.23 & 0.30 & 0.28 \\
LEA & $2.89 \mathrm{ABC}$ & $2.76 \mathrm{BC}$ & $3.31 \mathrm{ABC}$ & $3.54 \mathrm{AB}$ & $2.89 \mathrm{ABC}$ & $2.49 \mathrm{C}$ & $3.69 \mathrm{~A}$ & $3.18 \mathrm{ABC}$ \\
DFW & $87.00 \mathrm{AB}$ & $79.00 \mathrm{AB}$ & $77.00 \mathrm{~B}$ & $90.00 \mathrm{~A}$ & $87.00 \mathrm{AB}$ & $83.00 \mathrm{AB}$ & $84.00 \mathrm{AB}$ & $89.00 \mathrm{AB}$ \\
DSW & $7.70 \mathrm{AB}$ & $6.70 \mathrm{BC}$ & $6.40 \mathrm{C}$ & $7.20 \mathrm{BC}$ & $6.50 \mathrm{BC}$ & $7.60 \mathrm{ABC}$ & $6.60 \mathrm{BC}$ & $8.70 \mathrm{~A}$ \\
TEL & 38.15 & 38.57 & 38.45 & 39.26 & 38.57 & 37.94 & 38.67 & 37.88 \\
TEW & 16.55 & 16.34 & 16.61 & 17.29 & 16.76 & 17.11 & 17.10 & 18.82 \\
ANTL & $14.65 \mathrm{~A}$ & $13.39 \mathrm{BC}$ & $13.10 \mathrm{C}$ & $14.18 \mathrm{AB}$ & $13.55 \mathrm{BC}$ & $13.62 \mathrm{BC}$ & $13.55 \mathrm{BC}$ & $14.98 \mathrm{~A}$ \\
STIL & $31.39 \mathrm{AB}$ & $29.23 \mathrm{BC}$ & $28.62 \mathrm{C}$ & $30.53 \mathrm{ABC}$ & $29.71 \mathrm{BC}$ & $30.00 \mathrm{ABC}$ & $29.49 \mathrm{BC}$ & $32.23 \mathrm{~A}$ \\
CORN & 6.33 & 2.95 & 4.17 & 4.17 & 4.00 & 2.50 & 6.34 & 3.84 \\
CORD & $23.34 \mathrm{AB}$ & $19.09 \mathrm{~B}$ & $18.48 \mathrm{~B}$ & $17.24 \mathrm{~B}$ & $20.55 \mathrm{~B}$ & $20.89 \mathrm{~B}$ & $19.40 \mathrm{~B}$ & $31.35 \mathrm{~A}$ \\
FNPLO & $122.00 \mathrm{~A}$ & $12.00 \mathrm{C}$ & $9.50 \mathrm{C}$ & $22.50 \mathrm{C}$ & $24.50 \mathrm{C}$ & $22.50 \mathrm{C}$ & $54.00 \mathrm{~B}$ & $122.50 \mathrm{~A}$ \\
FNPLA & $8.14 \mathrm{~B}$ & $1.20 \mathrm{D}$ & $1.12 \mathrm{D}$ & $1.50 \mathrm{D}$ & $1.64 \mathrm{D}$ & $1.56 \mathrm{D}$ & $3.60 \mathrm{C}$ & $13.35 \mathrm{~A}$ \\
\hline
\end{tabular}

Average values followed by the same letter are not significantly different at $\mathrm{P} \leq 0.05$, Duncan test
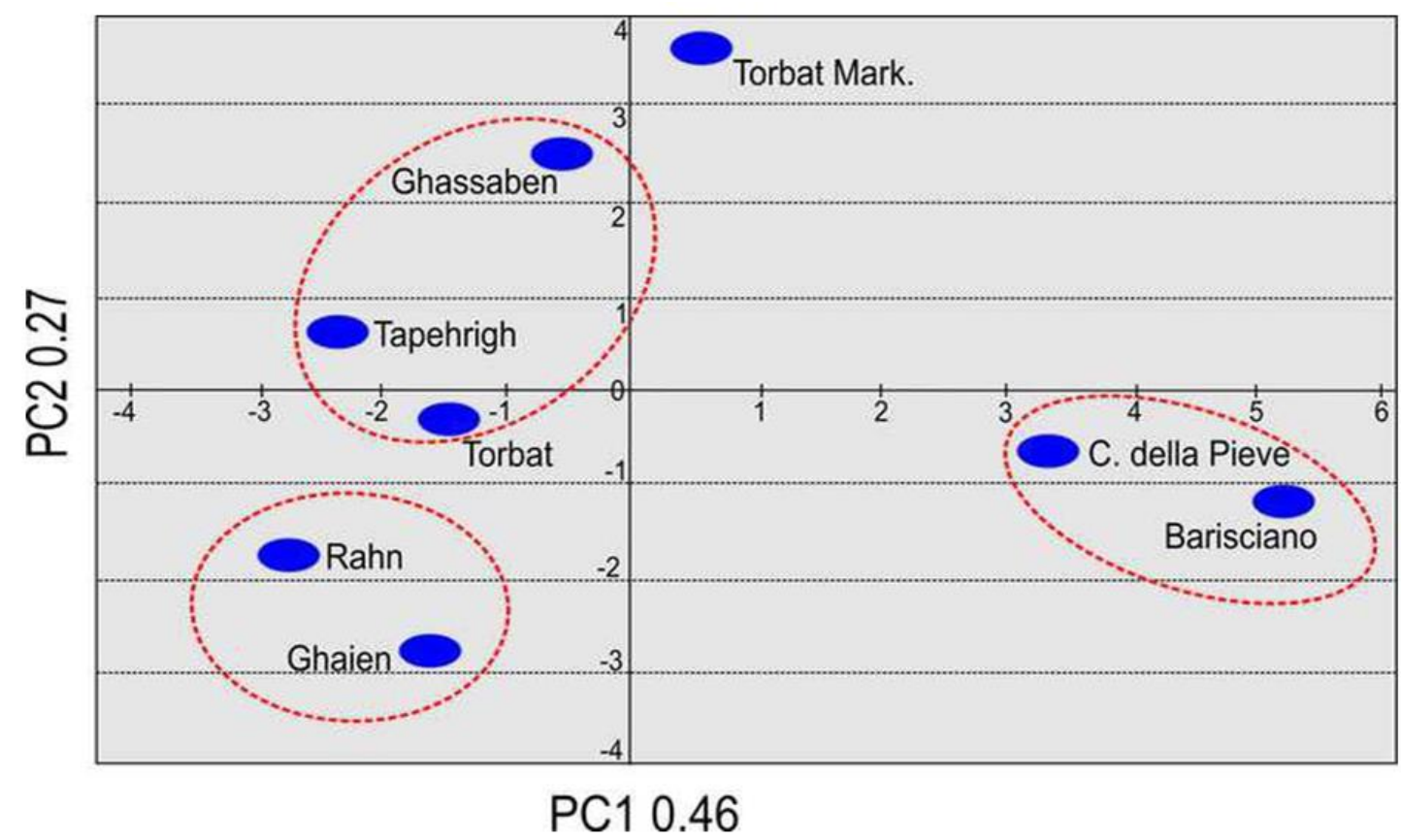

Figure 1. Principal component analysis based on the morpho-physiological traits recorded in the saffron populations 
Table 4. Pearson's correlation coefficients among 17 morpho-physiological traits

\begin{tabular}{|c|c|c|c|c|c|c|c|c|c|c|c|c|c|c|c|c|c|}
\hline TRAITS & DEME & BUNU & LENU & SHE & MLL & MLW & LEA & DFW & DWS & TEL & TEW & ANTL & STIL & CORN & CORD & FNPLO & FNPLA \\
\hline DEME & 1.00 & & & & & & & & & & & & & & & & \\
\hline BUNU & -0.41 & 1.00 & & & & & & & & & & & & & & & \\
\hline LENU & $-0.57^{*}$ & $0.69 * *$ & 1.00 & & & & & & & & & & & & & & \\
\hline SHE & -0.24 & 0.40 & 0.14 & 1.00 & & & & & & & & & & & & & \\
\hline MLL & $|-0.70 * *|$ & 0.11 & 0.00 & 0.31 & 1.00 & & & & & & & & & & & & \\
\hline MLW & $-0.73 * * \mid$ & 0.35 & 0.27 & 0.07 & $0.67 * *$ & 1.00 & & & & & & & & & & & \\
\hline LEA & $-0.73 * *$ & 0.22 & 0.08 & 0.17 & $0.92 * *$ & $0.89^{* * *}$ & 1.00 & & & & & & & & & & \\
\hline DFW & -0.24 & 0.16 & 0.31 & 0.29 & 0.31 & 0.10 & 0.23 & 1.00 & & & & & & & & & \\
\hline DWS & -0.22 & 0.18 & $0.65 * *$ & -0.09 & -0.10 & 0.00 & -0.09 & $0.68 * *$ & 1.00 & & & & & & & & \\
\hline TEL & -0.13 & -0.12 & -0.20 & 0.28 & $0.55^{*}$ & 0.25 & $0.42 *$ & $\mid 0.50^{*}$ & 0.07 & 1.00 & & & & & & & \\
\hline TEW & -0.21 & -0.06 & -0.06 & 0.34 & $0.48^{*}$ & 0.04 & 0.26 & $0.63 * *$ & 0.35 & $0.79 * *$ & 1.00 & & & & & & \\
\hline ANTL & $-0.51^{*}$ & $0.42 *$ & $0.77^{* *}$ & 0.21 & 0.15 & 0.21 & 0.14 & $0.62 * *$ & $0.76^{* * *}$ & 0.11 & 0.30 & 1.00 & & & & & \\
\hline STIL & -0.37 & 0.30 & $0.72 * *$ & 0.23 & 0.07 & 0.10 & 0.04 & $0.80 * *$ & $0.88^{* * *}$ & 0.26 & 0.41 & $0.86^{* * *}$ & 1.00 & & & & \\
\hline CORN & -0.37 & $0.70^{* *}$ & 0.28 & 0.30 & 0.40 & $0.48^{*}$ & $0.47 *$ & 0.29 & 0.00 & 0.21 & 0.26 & 0.29 & 0.12 & 1.00 & & & \\
\hline CORD & -0.36 & 0.18 & $0.75^{* * *}$ & 0.09 & -0.16 & -0.02 & -0.16 & 0.26 & $0.66 * *$ & $\mid-0.26$ & -0.08 & |0.55* & $0.65 * * \mid$ & -0.30 & 1.00 & & \\
\hline FNPLO & $-0.54 *$ & $0.70 * *$ & 0.97 ** & 0.22 & 0.00 & 0.20 & 0.04 & $\left|0.45^{*}\right|$ & $0.70^{* * *}$ & $\mid-0.18$ & 0.04 & $0.84 * *$ & $0.78 * * \mid$ & 0.36 & $0.72^{* * *}$ & 1.00 & \\
\hline FNPLA & $-0.59^{*}$ & $0.53 *$ & $0.94 * *$ & 0.06 & 0.00 & 0.21 & 0.05 & \begin{tabular}{|l|l|} 
& $0.42 *$ \\
\end{tabular} & $0.74 * *$ & -0.20 & 0.04 & $0.83 * *$ & $0.78 * *$ & 0.22 & $0.80 * *$ & $0.96 * *$ & 1.00 \\
\hline
\end{tabular}

Days to emergence (DEME), Buds number in vegetation (BUNU), Leaves number per bud (LENU), sheath height (SHE), main leaf length (MLL), main leaf width (MLW), leaf area (LEA), Dry flower weight (DFW), Dry weight of stigmas (DWS), Tepals length (TEL), Tepals width (TEW), Anther length (ANTL), Stigma length (STIL), Corms number per plant (CORN), Corms diameter (CORD), Flowers number per plot (FNPLO), Flowers number per plant (FNPLA)

Table 5. Principal component analysis based on morpho-physiological traits of 8 saffron accessions, and significant loadings (in bold) of the first three principal components

\begin{tabular}{c|c|c|c}
\hline & PC1 & PC2 & PC3 \\
\hline Eigenvalue & 7.8453 & 4.5590 & 2.0457 \\
Percent of total variation & 0.4615 & 0.2682 & 0.1203 \\
Cumulative & 0.4615 & 0.7297 & 0.8500 \\
DEME & -0.2484 & -0.2618 & 0.0746 \\
BUNU & 0.23669 & 0.1325 & -0.3196 \\
LENU & 0.3378 & -0.0630 & -0.2014 \\
SHE & 0.1011 & 0.1998 & 0.1999 \\
MLL & 0.0459 & 0.4483 & 0.0924 \\
MLW & 0.1326 & 0.3467 & -0.2711 \\
LEA & 0.0681 & 0.4365 & -0.0456 \\
DFW & 0.2319 & 0.0836 & 0.4714 \\
DWS & 0.2893 & -0.1971 & 0.1968 \\
TEL & -0.1573 & 0.3400 & 0.1771 \\
TEW & 0.0271 & 0.2153 & 0.5262 \\
ANTL & 0.3280 & -0.0595 & 0.1800 \\
STIL & 0.3237 & -0.1008 & 0.2219 \\
CORN & 0.1668 & 0.3008 & -0.2492 \\
CORD & 0.2999 & -0.1914 & -0.0237 \\
FNPLO & 0.3498 & -0.0535 & -0.0918 \\
FNPLA & 0.3437 & -0.0822 & -0.0755 \\
\hline
\end{tabular}

A graphic representation of saffron accession genetic similarity level, based on a cluster analysis, is showed in Figure 2. With the exception of the saffron population coming from Spain, which showed to be well differentiated from all others, all the accessions are grouped into two main clusters (A and B). Cluster A consists of two sub- 
groups: the first includes all Umbrian accessions (Cascia, Città della Pieve, and S. Anatolia di Narco). In particular, with the primer combinations used, accessions from Città della Pieve and S. Anatolia di Narco showed no molecular differences. The second sub-group consists of two Iranian populations (Rahn and Ghaien) and the population belonging to Abruzzo Region (Barisciano). Cluster B grouped all the remaining Iranian populations (Ghassabbeh, Torbat, Tapehrig, and Torbat_Market). However, in cluster B it is also possible to distinguish two sub-clusters: the first includes the accession collected both in Tapehrigh and in the market (Torbat Market), the second sub-cluster gathers one accession from Torbat and one from Ghassabeh.

Table 6. Primer combinations and level of AFLP polymorphisms

\begin{tabular}{c|c|c|c|c|c}
\hline $\begin{array}{c}\text { Primer } \\
\text { combinations }\end{array}$ & $\begin{array}{c}\text { Fragment size } \\
\text { (bp) }\end{array}$ & $\begin{array}{c}\text { Number of } \\
\text { fragments }\end{array}$ & $\begin{array}{c}\text { Monomorphic } \\
\text { fragments }\end{array}$ & $\begin{array}{c}\text { Polymorphic } \\
\text { fragments }\end{array}$ & $\begin{array}{c}\text { Polymorphic } \\
\text { \% }\end{array}$ \\
\hline EcoCCA/MseACC & $54-347$ & 56 & 52 & 4 & 7.14 \\
EcoCCA/MseAGC & $55-389$ & 47 & 43 & 4 & 8.51 \\
EcoCCA/MseACA & $52-268$ & 30 & 29 & 1 & 3.33 \\
EcoCCA/MseAAC & $51-311$ & 28 & 27 & 1 & 3.57 \\
EcoCAA/MseACC & $51-338$ & 47 & 46 & 1 & 2.13 \\
EcoCAA/MseAGC & $52-351$ & 61 & 61 & 0 & 0.00 \\
EcoCAA/MseACA & $60-281$ & 24 & 22 & 2 & 8.33 \\
EcoCAA/MseATC & $51-309$ & 25 & 25 & 0 & 0.00 \\
\hline Total & - & 318 & 305 & 13 & - \\
\hline Mean & - & 39.75 & 38.13 & 1.63 & 4.13 \\
\hline
\end{tabular}

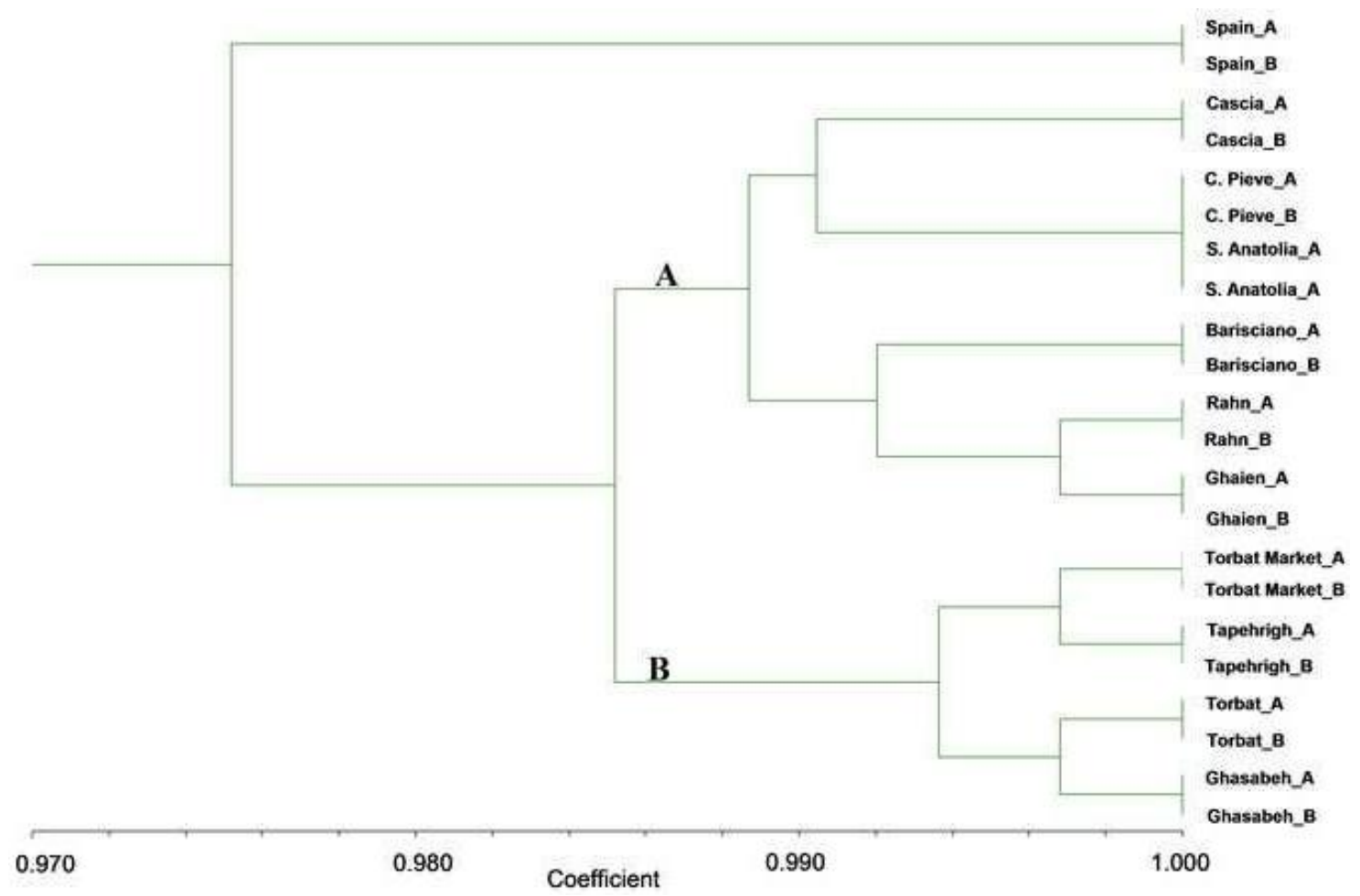

Figure 2. UPGMA clustering of the saffron populations based on the Jaccard's genetic similarity matrix 


\section{Discussion}

In this study, a morpho-physiological and molecular characterization was developed for investigating the existing diversity among different populations of $C$. sativus $\mathrm{L}$. Analysis of variance of the morpho-physiological data shows that the Italian accessions of saffron yielded a greater number of flowers than the Iranian accessions. Regarding to the diameter of the corms, highly correlated with the production of flowers, the Italian accessions (in particular Barisciano) showed higher values than those collected in Iran. This is probably due to the traditional practice of the annual selection of bigger corms carried out in Abruzzo (Gresta et al., 2008a), and the increased availability of water and nutrients. Barisciano accession was also characterized by the earliest emergence of leaves and by the highest length of the stigmas. In the present work, the morphophysiological characteristics of the leaves, flower and corms allowed to discriminate saffron populations. This result highlights the usefulness of the morphological characterization of local germplasm, especially in the early stages of the genetic characterization. Indeed, the morpho-physiological traits have allowed a clear discrimination of the Italian accessions from those collected in Iran and in the Torbat market.

For the genetic characterization the AFLP markers were chosen among other classes of molecular markers because they do not require a priori knowledge of the genome of the species, further more they are highly informative and reproducible. The eight AFLP primer combinations discriminated the Spanish accession from all other saffron populations. In addition, this study showed that populations belonging to Umbria (Cascia, Città della Pieve, S. Anatolia di Narco) may have the same genetic origin, as they show no or very little molecular differences. Probably the original saffron was spread through Umbria by exchange of corms between farmers and this is particularly true for saffron belonging to Città della Pieve and $\mathrm{S}$. Anatolia di Narco. The Abruzzo population (Barisciano), although belonging to the same cluster (cluster A) of other Italian populations, seems to be genetically closer to two Iranian populations (Rhan and Ghaien). The other four Iranian populations were grouped apart from other accessions in a separate cluster (cluster B) (Fig. 2).

\section{Conclusion}

The results of this study partially confirm obtained in previous studies carried out in saffron (Grilli Caiola and Canini, 2004). However, according to (Fernandez, 2007) it is possible to find different saffron products on the market. This may be due to the growing environment, to the collection and processing of spice, but probably also to genetic differences between the different clonal populations. For instance in Navelli (Abruzzo Region - Italy) the selection of corms carried out each year has produced a significant "genetic pool" with respect to corm dimensions and disease resistance (Gresta et al., 2008a). The same results eas shown in comparison the results of this study, with other saffron research's (Yousefi Javan and Gharari, 2018), using the other molecular markers for prove genetic diversity. The main difference between the two studies is use of different markers and different regions.

Particularly in this study, despite several morphological differences found between accessions, molecular markers (AFLP) have revealed limited genetic differences in particular for Italy and Iran (Genetic Similarity $=0.985$ ) samples. Also in another research with the different markers, $C$. sativus demonstrated minimal genetic variation, 
in contrast to the intraspecific variability seen in other Crocus species, and it is concluded that the triploid hybrid species has most probably happened only once. The data show that saffron is an allotriploid species, with the IRAP analysis indicating that the most likely ancestors are C. cartwrightianus and C. pallasii subsp. Pallasii (or close relatives). The results may facilitate resynthesizing saffron with improved characteristics, and show the need for conservation and collection of wild Crocus.

The vegetative multiplication limits for this crop the application of conventional breeding approaches for its further improvement. The selection of the best lines among natural or cultivated populations is restricted to searching for a quote of variability deriving from some rare mutations.

Therefore greater efforts must be made to investigate the genetic variability in this crop that is having an increasing economic value. Looking for saffron populations, that have retained some level of sexual reproduction, with the aim of crossing and selecting new types, could be a further challenge.

\section{REFERENCES}

[1] Abdullaev, F. I. (2002): Cancer chemopreventive and tumoricidal properties of saffron (Crocus sativus L.). - Experimental and Biological Medicine 227(1): 20-5.

[2] Abrishami, M. H. (1987): Undrestanding of Iranian Saffron. - Tous, Tehran.

[3] Abrishami, M. H. (2004): Saffron, from yesterday till today, an encyclopaedia of its production, trade and use. - Amirkabir, Tehran.

[4] Agayev, Y. M., Shakib, A. M., Soheilivand, S., Fathi, M. (2006): Breeding of saffron (Crocus sativus): possibilities and problems. - Acta Horticulturae (ISHS) 739: 203-207.

[5] Agayev, Y. M., Fernandez, J. A., Zarifi, E. (2009): Clonal selection of saffron (Crocus sativusL.): the first optimistic experimental results. - Euphytica169: 81-99.

[6] Alavi Kia, S. S., Mohammadi, S. A., Aharizad, S., Moghaddam, M. (2008): Analysis of genetic diversity and phylogenetic relationships in Crocus genus of Iran using interretrotransposon amplified polymorphism. - Biotechnology Equipment 22: 795-800. (In persian).

[7] Albertini, E., Torricelli, R., Bitocchi, E., Raggi, L., Marconi, G., Pollastri, L., Di Minco, G., Battistini, A., Papa, R., Veronesi, F. (2011): Structure of genetic diversity in Olea europaea L. cultivars from central Italy. - Molocular Breeding 27: 533-547.

[8] Aung, H. H., Wang, C. Z., Ni, M. (2007): Crocin from Crocus sativus possesses significant anti-proliferation effects on human colorectal cancer cells. - Exprimental Oncology 29(3): 175-80.

[9] Babaei, S., Talebi, M., Bahar, M., Zeinali, H. (2014): Analysis of genetic diversity among saffron (Crocus sativus) accessions from different regions of Iran as revealed by SRAP markers. - Scientia Horticulturae 171: 27-31.

[10] Beiki, A. H., Keifi, A., Mozafari, J. (2010): Genetic differentiation of Crocus species by random amplified polymorphic DNA. - Genetic Engineering Biotechnology Journal 18: 1-10 (in Persian).

[11] Chryssanthi, D. G., Lamari, F. N., Iatrou, G., Pylara, A., Karamanos, N. K., Cordopatis, P. (2007): Inhibition of breast cancer cell proliferation by style constituents of different Crocus species. - Anticancer Research 27(1a): 357-62.

[12] Dadkhah, M., Ehtesham, M., Fekrat, H. (2003): Iranian Saffron an Unknown Jewel. Shahr Ashub Publication, Tehran.

[13] Erol, O., Şık, L., Kaya, H. B., Tanyolaç, B., Küçüker, O. (2011): Genetic diversity of Crocus antalyensis B. Mathew (Iridaceae) and a new subspecies from southern Anatolia. - Plant System Evolution 294: 281-287. 
[14] Erol, O., Kaya, H. B., Azik, L., Tuna, M., Can, L., Tanyolac, M. B. (2014): The genus Crocus, series Crocus (Iridaceae) in Turkey and 2 East Aegean islands: a genetic approach. - Turkish Journal of Biology 38: 48-62.

[15] Fernandez, J. A. (2004): Biology, biotechnology e biomedicine of saffron. - Recent Research Development Plant Science 2: 127-165.

[16] Fernandez, J. A. (2007): Genetic resources of saffron and allies (Crocus spp.). - Acta Horticulture 739: 167-185.

[17] Fluch, S., Hohl, K., Stierschneider, M., Kopecky, D. (2010): Crocus sativus L. Molecular evidence on its clonal origin. - Acta Horticulturae 850: 41-46.

[18] Ghaffari, S. M., Bagheri, A. (2009): Stigma variability in saffron (Crocus sativus L.). African Journal of Biotechnology 8: 601-604.

[19] Gresta, F., Lombardo, G. M., Ruberto, G., Siracusa. L. (2008a): Saffron, an alternative crop for sustainable agricultural systems: a review. - Agronomy for Sustainable Development 28(1): 95-112.

[20] Gresta, F., Lombardo, G. M., Siracusa, L., Ruberto, G. (2008b): Effect of mother corm dimension and sowing time on stigma yield, daughter corms and qualitative aspects of saffron (Crocus sativus L.) in a Mediterranean environment. - Journal of Science of Food and Agriculture 88(77): 1144-50.

[21] Gresta, F., Avola, G., Albertini, E., Raggi, L., Abbate, V. (2010): A study of variability in the Sicilian faba bean landrace 'Larga di Leonforte. - Genetic Resource Crop Evolution 57: 523-531.

[22] Grilli Caiola, M., Canini, A. (2004): Ultrastructure of chromoplasts and other plastids in Crocus sativus L. (Iridaceae). - Plant Biosystems 138(1): 43-52.

[23] Grilli Caiola, M., Canini, A. (2010): Looking for saffron's (Crocus sativus L.) Parents. Functional Plant Science and Biotechnology 4(Special Issue 2): 1-14.

[24] Grilli Caiola, M., Caputo, P., Zaier, R. (2004): RAPD analysis in Crocus sativus L. accessions and related Crocus species. - Biologia Plantarum 48: 375-380.

[25] Gutheil, W. G., Reed, G., Ray, A., Anant, S., Dhar, A. (2012): Crocetin: an agent derived from saffron for prevention and therapy for cancer. - Current Pharmacy and Biotechnology 13(1): 173-9.

[26] Hosseinzadeh Gonabad, Y. (2013): Caratterizzazione morfologica e molecolare dello zafferano (Crocus sativus L.) iraniano (Khorasan). - Tesi di Dottorato di Ricerca, Università degli Studi di Perugia.

[27] Jaccard, P. (1908): Nouvelles recherches sur la distribution florale. - Bulgaria Soc Vaudoise Sci Nat 44: 223-270.

[28] Kim, S. H., Lee, J. M., Kim, S. C., Park, C. B., Lee, P. C. (2014): Proposed cytotoxic mechanisms of the saffron carotenoids crocin and crocetin on cancer cell lines. Biochemistry of Cell Biology 92(2): 105-11.

[29] Lage, M., Cantrell, C. L. (2009): Quantification of saffron (Crocus sativus L.) metabolites crocins, picrocrocin and safranal for quality determination of the spice grown under different environmental Moroccan conditions. - Sciencia Horticulture 121(3): 366-73.

[30] Meudt, H. M., Clarke, A. C. (2007): Almost forgotten or latest practice? AFLP applications, analyses and advances. - Trends Plant Science 12: 106-117.

[31] Molina, R. V., Guardiola, J. L., García-Luis, D. (2015): Descriptors for Crocus (Crocus spp.). - Bioversity International, Rome.

[32] Nazzal, K. W., Shibli, R. A., Makhadmeh, I. M., Syouf, M. Q. (2011): Amplified fragment length polymorphism (AFLP) analysis in Crocus spp. collected from Northern Jordan. - Jordan Journal of Agricultural Sciences 7: 1-8.

[33] Nehvi, F. A., Wani, S. A., Dar, S. A., Makhdoomi, M., Allie, B. A., Mir, Z. A. (2007): Biological interventions for enhancing saffron productivity in Kashmir. - Acta Horticulturae739: 25-32.

[34] Nemati, Z. M., Zeinalabedini, M., Mardi, S. M., Pirseyedi, S., Marashi, S. Khyam Nekoui, S. M. (2012): Isolation and characterization of a first set of polymorphic 
microsatellite markers in saffron, Crocus sativus (Iridaceae). - American Journal of Botany 99(9): 340-343.

[35] Pearce, F. (2005): Returning War-Torn Farmland to Productivity. - New Scientist, September 2011. https://cyrussaffron.com/the-history-of-saffron/.

[36] Petersen, G., Seberg, O., Thorsøe, S., Jørgensen, T., Mathew, B. (2008): A phylogeny of the genus Crocus (Iridaceae) based on sequence data from five plastid regions. - Taxon 57: 487-499.

[37] Pfander, H., Wittwer, F. (1975): Carotenoid composition in safran. - Helv Chimistry Acta 58: 2233-2236.

[38] Powell, W., Morgante, M., Andre, C., Hanafey, M., Vogel, J., Tingey, S., Rafalski, A. (1996): The comparison of RFLP, RAPD, AFLP and SSR (microsatellite) markers for germplasm analysis. - Molocular Breeding 2: 225-238.

[39] Premkumar, K., Thirunavukkarasu, C., Abraham, S. K., Santhiya, S. T., Ramesh, A. (2006): Protective effect of saffron (Crocus sativus L.) aqueous extract against genetic damage induced by anti-tumor agents in mice. - Human Experiment Toxicology 25(2): 79-84.

[40] Rubio Moraga, A., Traper-Mozos, A., Gómez-Gómez, L., Ahrazen, O. (2010): Intersimple sequence repeat markers for molecular characterization of Crocus cartwrightianus cv. Albus. - Indian Crops Production 32: 147-151.

[41] Rohlf, E. J. (1993): NTSYS-pc: Numerical Taxonomy and Multivariate Analysis System. Version 1.80. - Applied Biostatistics Inc., Setauket, New York.

[42] SAS (2008): SAS/STAT 9.2 User's Guide. - SAS Institute Inc, Cary, NC.

[43] Singh, M., Singh, P., Juneja-Pawan, K., Singh, S., Kaur, T. (2010): SNP-SNP interactions within APOE gene influence plasma lipids in postmenopausal osteoporosis. Rheumatology International 31(3): 421-3.

[44] Siracusa, L., Gresta, F., Avola, G., Albertini, E., Raggi, L., Marconi, G., Lombardo, G., Ruberto, G. (2013): Agronomic, chemical and genetic variability of saffron (Crocus sativus L.) of different origin by LC-UV-vis-DAD and AFLP analyses. - Genetic Research Crop Evolution 60: 711-721.

[45] Sneath, P. H. A., Sokal, R. R. (1973): Numerical Taxonomy. - Freeman, San Francisco, USA.

[46] Syvanen, A. (2001): Accessing genetic variation: genotyping single nucleotide polymorphisms. - Nature 2: 930-942.

[47] Torricelli, R., Silveri, D. D., Ferradini, N., Venora, G., Veronesi, F., Russi, L. (2012): Characterization of the lentil landrace Santo Stefano di Sessanio from Abruzzo, Italy. Genet Resource Crop Evolution 59: 261-276.

[48] Torricelli, R., Tiranti, B., Spataro, G., Castellini, G., Albertini, E., Falcinelli, M., Negri, V. (2013): Differentiation and structure of an Italian landrace of celery (Apium graveolens L.): inferences for on farm conservation. - Genetic Resources and Crop Evolution. 60: 995-1006.

[49] Tsimidou, M., Tsatsaroni, E. (1993): Stability of saffron pigments in aqueous extracts. Journal of Food Science Food 58: 1073-1075.

[50] Vos, P., Hogers, R., Bleeker, M., Reijans, M., Van De Lee, T., Hornes, M., Frijters, A., Pot, J., Peleman, J., Kuiper, M., Zabeau, M. (1995): AFLP: A new technique for DNA fingerprinting. - Nuclear Acids Research 23: 4407-4414.

[51] Winterhalter, P., Straubinger, M. (2000): Saffron renewed interest in an ancient spice. Food Revolution International 16(1): 39-59.

[52] Yousefi-Javan, I., Gharari, F. (2018): Genetic diversity in saffron (Crocus sativus L.) cultivars grown in Iran using SSR and SNP markers. - Journal of Agricultural Science and Technology 20: 1213-1226.

[53] Zubor, A. A., Suranyi, G., Gyori, Z., Borbely, G., Prokish, J. (2004): Molecular biological approach of the systematic of Crocus sativus L. and its allies. - Acta Horticulturae 650: 85-9. 